\title{
19. State-owned enterprise reform in China: Past, present and prospects
}

\section{Ligang Song ${ }^{1}$}

Reform of state-owned enterprises (SOEs) has been a core element of China's economic reform process over the past 40 years. SOEs formed the backbone of China's economy during the central planning era; their transformation is the most prominent among changes in China's enterprise system that have been taking place in tandem with other institutional and policy reforms in the course of the transition to a market-based economy. Market-oriented development has progressed with a reduction in the scope of the SOE sector in the economy. Unlike what has happened in the former socialist countries in Europe, in China, SOE reform did not involve rapid and widespread privatisation (Naughton 2007; Zhang 2009). China's reformers have been aware of the significant economic, social and political consequences of disruption caused by breaking up SOEs in a short time without creating the necessary conditions for change (McMillan and Naughton 1992). Therefore, China's economic transition is recognised for its gradualist and experimental approach to reform, with SOE reform a typical example. The primary goal of market-oriented reforms, as repeatedly reiterated by the Chinese Government, is to build a socialist market economy with the state-owned sector as a leading sector. This thinking and practice have had significant implications for the outcome of previous SOE reforms, as well as for the direction of future changes to the SOE sector.

SOE reforms have contributed to China's economic development in two ways: first, changes to SOEs have made room and created the necessary conditions for the emergence and flourishing of private enterprises and enterprises with other ownership forms. Second, such change has also helped to enhance the efficiency and competitiveness of SOEs, leading to the substantial growth of their output, which in turn enables SOEs, especially the large ones, to maintain their substantial share in the economy. Reforms have so far created a new generation of SOEs with diversified ownership types and a significant level of internationalisation. Now there are only a small number of SOEs that are purely state owned, with the majority of enterprises now state-controlled shareholding corporations.

1 I thank Son Ngoc Chu and Shenglang Yang for sourcing the background materials, including the data for the tables and figures. 
This chapter begins with an analytical account of China's SOE reforms during the transition process. This section highlights the core issues of SOE operation, governance and performance that have been addressed across the different stages of reform. Issues include market competition and the soft budget constraint, ownership transformation, autonomy, enterprise monitoring and corporate governance and commercial objectives and policy functions of the SOEs. The chapter shows how these core issues have evolved and how China's gradualist and dual-track approach to market transition has taken place. Using a chronological approach and highlighting the consistency of SOE reforms within China's overall reform program, this chapter examines the SOE reform process in four stages: 1978-92, 1992-2003, 2003-13 and 2013 to the present. The chapter provides concluding remarks on the prospects of current SOE reform efforts.

\section{The nature of SOEs and China's approach to SOE reforms in transition}

SOEs were the main economic units in the enterprise system of nonagricultural sectors under the central planning system. The primary functions of SOEs were to fulfil the government's objectives for production and distribution of goods. The government played a crucial role in planning, coordination and resource allocation, while SOEs had little autonomy in determining what and how much to produce, adjusting the workforce or deciding on the use of surpluses or profits. Product prices did not function as the primary signal to guide an enterprise's production decisions, but instead were used by the government to channel resources between economic sectors, particularly the industrial sector for ambitious industrialisation plans (Naughton 2007: 60). Moreover, as government agents, SOEs were responsible for employees' welfare and that of their families, including housing, health care, education and retirement (Chow 2002: 69). The lack of market-based incentives and multiple functions of SOEs led to their low efficiency, contributing to the chronic problems of low output and shortages during the planned economy period. Because of these problems, SOE transformation is among the most significant areas of economic transition-namely, adopting a market mechanism for resource allocation and promoting efficiency with output expansion. In the literature on SOEs, the approach to reform and associated policy measures has focused on the following critical issues of enterprise performance.

\section{Market competition and the soft budget constraint}

Under central planning SOEs did not have to compete with each other or with enterprises of other ownership forms on the market to buy inputs and sell output. Instead, SOEs relied on the government agencies in their respective sectors for 
production needs and output distribution through 'material balance planning' (Naughton 2007: 61). It is, therefore, a primary step in SOE reform to expose the sector to market competition. Moreover, SOEs had few concerns about efficiency when making decisions on investment and production, other than meeting the output targets set by the government. They were financially dependent and supported by the government through different channels, including funding from state-owned banks and other fiscal sources from different government agencies, which Kornai (1986) in his seminal paper called 'The soft budget constraint'. Typically, subsidies, tax exemptions and soft credits are the key channels to help firms soften their budget constraint. As a result, they are less responsive to price signals and market rules and prone to losses and state assistance. SOEs' chronic soft budget constraint problem not only occurred under central planning, but also persisted into the market transition period (Kornai et al. 2003: 1095).

\section{Ownership transformation}

Given the dominant share of the SOE sector in the centrally planned economy, a key policy measure of China's SOE reforms is ownership change by reducing the government's holdings of SOE assets through partial or full privatisation of SOEs. This measure has the dual effects of reducing the government's cost burden from inefficient SOEs and creating opportunities for private firms to participate and expand (Garnaut et al. 2006). Ownership reform was, therefore, a cornerstone of the market reform program that began with the government's recognition of a multi-ownership economic system and private property rights (Chow 2002). The economy-wide ownership reform played a crucial role in the emergence of nonstate enterprises, significantly enhancing market competition in the early period of transition (Jefferson and Su 2006).

\section{Autonomy, enterprise monitoring and corporate governance}

The functioning of a market economy requires that the property rights of economic agents are clearly defined and enforced. In principle, SOEs are owned by the people and controlled by the government. The primary objective of SOE reform is to reduce government intervention in business operations and provide autonomy and delegate the use rights of SOE assets to managers. As a consequence, there is a separation between the owners and managers or ownership and control, giving rise to the principal-agent problem. The agency cost theory suggests that enterprise managers with the advantage of insider information may abuse their power to benefit themselves. The problem is usually more pervasive in SOEs due to the weak monitoring of assets caused by high costs of monitoring, as well as the lack of incentives created by the entrenched interests of supervisory agency officials (Milhaupt and Zheng 2015). This is why the issue of giving autonomy to 
and monitoring SOEs has been recurrent despite substantial changes in the scope of government and enterprise relations during different periods of reform. In the 1980s, enterprise autonomy was central among reform measures (Huang 1999). After 30 years, in the latest round of SOE reforms, increasing enterprises' independence is still a key objective of policymakers (Naughton 2016).

\section{Commercial objectives and policy functions of SOEs and the sectoral dimension of SOE reform}

Besides corporate governance, another crucial aspect of the complicated relationship between the government and SOEs in China is the dual nature of assigning functions to SOEs in the design of reform measures. On the one hand, supervisory agencies of central and local governments require SOEs to be profit oriented. On the other hand, SOEs are assigned to carry out government policy objectives. To some extent, the 'iron rice bowl' concept - a legacy of central planning-has maintained SOEs' substantial social welfare responsibilities for their employees, although this has been declining over time. It is, therefore, an expectation that SOEs will play an essential role in maintaining social stability by providing employment and protection of workers' welfare, especially when the social safety net is underdeveloped or when there are economic shocks. Over the past few decades, SOEs have played an essential role in developing large-scale infrastructure projects, carried out by governments at both central and local levels to support economic growth. SOEs have also been considered key instruments in promoting technological advances, securing strategic resources and advancing national interests. These government interests have been realised in selective industrial policies, which have a significant influence on the measures and practices of SOE reform, as seen in their sectoral distribution. There are specific government-directed works that were carried out by SOEs with public good properties. These policy functions have made it difficult to assess the performance of SOEs and the outcome of reforms. In presenting the multitask theory of SOEs, Bai et al. (2006) propose, and provide evidence of, how the low economic performance of SOEs is attributable to the multi-objective nature of their operation.

It is essential to consider these issues when reviewing the SOE reform process, as they are crucial aspects of SOEs' operation and development. Chronologically, the process of SOE reforms can be divided into four stages, marked by important policy documents and reform initiatives promulgated by the Communist Party of China (CPC) and the Chinese Government in line with their broad economic reform agenda. 


\section{Autonomy with the contract responsibility system and competition, 1978-92}

At the beginning of the economic transition, state ownership of SOEs remained intact due to strong ideological and political perceptions of the need for the state to control all critical means of production (Chow 2002). Within that boundary, reform measures to improve the performance of SOEs were focused on granting autonomy to state enterprises and introducing a market mechanism.

In the early 1980s, an enterprise responsibility system was implemented based on the success of the household responsibility system, which had been introduced in the agricultural sector. The primary objective of the program was to increase SOEs' productivity, output and profitability. After fulfilling state plans and output quotas, enterprises were allowed to keep a share of total profits from production and make decisions about production plans, workforce adjustment and product marketing. In 1984, enterprise rights were extended to production planning, purchase of inputs, worker payment and recruitment, staffing and the use of retained profits. Under the contract system, each SOE was allowed to adopt a compulsory plan or market-oriented scheme. Under the compulsory scheme, the enterprise had to fulfil an output quota to be sold to the state at state-set prices, but it was supplied with material inputs at planned prices. Under the market-oriented scheme, the enterprise was allowed to sell on the market but had to buy material inputs at market prices (Chow 2002). As a result of providing greater autonomy and incentives, the program - initially trialled on 100 enterprises in Sichuan provincewas quickly adopted and applied to 6,600 SOEs in 1980, to 42,000 in 1981 and almost the entire industrial sector in 1983 (Huang 1999: 99). In 1985, the contract responsibility system was introduced into the state industrial sector to create a formalised relationship between SOEs and the responsible government agency. The system was developed with greater emphasis on enterprises' responsibilities for profits and losses and more stable quotas on output and profits. By the end of 1988, the contract system had been applied to about 93 per cent of SOEs (Huang 1999: 102). At the same time, a two-tier price system was introduced (Chow 2002). The contract and two-tier price systems represent the typical dual-track and incremental approach to China's SOE reforms, with planning-based and marketbased coordination mechanisms (Naughton 2007). These systems were gradually eliminated over time with the increasing introduction of market competition.

The contract responsibility system entailed the emergence of industrial product markets and competition among SOEs. At the same time, the government removed entry barriers to and encouraged the development of nonstate enterprises-mainly industrial collectives, and principally township and village enterprises (TVEs) and foreign-funded firms, especially those from Hong Kong, Macau and Taiwan (HMT). While there was no change in ownership within SOEs, this reform measure 
led to diversified ownership types in the whole industrial sector, creating significant competition in many industries (Jefferson and Su 2006). Another important reason for the rapid development ofTVEs, mostly at the local level, was the decentralisation process in the mid-1980s that saw the delegation to local governments of more autonomy over budget revenue. This created incentives for local governments to support local businesses for greater revenue sources and a broader tax base.

Enterprise autonomy and market entry led to significant changes in the SOE sector that were conducive to China's industrial growth in the 1980s and early 1990s. Between 1978 and 1994, while the number of SOEs increased slightly, from 83,700 to 102,200 , the number of collective enterprises, including TVEs, increased sharply, from 264,700 to 1.86 million units, and the number of individually owned and other enterprises reached 800,000 . The total number of reported industrial enterprises surged from 300,000 to 10.02 million. Consequently, the SOEs' share in China's total gross industrial output declined from 78 per cent to 37.4 per cent. The percentage of collective enterprises grew to 37.7 per cent, surpassing that of SOEs (Jefferson 2016: 9). The trend of output share is consistent with that of output growth for industrial enterprises. In the period 1980-91, the annual output growth of SOEs was 7.8 per cent, while that of collectives was 18.6 per cent and of private enterprises, 140.6 per cent (Rawski 1994: 272). Despite slower growth, SOEs were an essential source for the growing emergence of collective and private enterprises' access to equipment, technical information, management skills and subcontracting opportunities (Rawski 1994). As a result of reform, industrial product markets were increasingly competitive, eliminating quasi-rents due to entry barriers, while the level of competition varied significantly across light and heavy industries (Jefferson and Rawski 1994). The main goal of dismantling the central planning system in the industrial sector as the first step of moving to a market mechanism was almost complete (Naughton 2007). Private sector growth occurred despite a lack of marketsupporting institutions, especially clearly defined property rights.

The initial reform measures had significant effects on the performance of SOEs, which can be assessed using indicators of productivity, efficiency and financial performance. ${ }^{2}$ Some studies found evidence that some of the SOEs surveyed had improved their labour and total factor productivity (TFP) through facing market competition (Jefferson and Rawski 1994; Huang 1999). However, SOEs recorded worsening financial performance throughout the reform period, especially after the mid-1980s. The SOE profit rate (returns on fixed assets, or ROFA) declined from 18 per cent in 1985 to below 6 per cent in the early 1990s, with an increasing number of lossmaking enterprises and substantial total losses (Song 2015: 184).

2 There is variation in efficiency and productivity estimates and their links with SOE reform measures among the empirical studies on Chinese industrial enterprises due to differences in sample selection, aggregation levels and methodologies, as documented by Huang (1999). This chapter is focused more on financial performance indicators, while some productivity performance measures are used selectively. 
As a result, not only did SOEs' contribution to government revenue decline, but also there was a rising problem with soft budget constraints among SOEs, despite the government's efforts to cope with the problem. It was estimated that total fiscal and monetary subsidies to industrial SOEs grew from RMB6.3 billion (1.4 per cent of gross national product, or GNP) in 1980 to RMB268 billion (10 per cent of GNP) in 1992 (Huang 1999: 113).

While the increased market competition could be a leading cause of SOEs' worsening performance, other reasons emerged to do with underlying issues of SOE functions, management and monitoring. First, in the context of early transition, there was no social security system. SOEs had to bear policy burdens relating, in particular, to expenses for health care, housing and education for their workers, as a legacy of the central planning era, and also had to act as a social safety net maintaining employment for redundant workers (McMillan and Naughton 1992; Song 2015). Second, it appears the contract responsibility system was an initial step towards changing the enterprise-government relationship by replacing the government's direct control of enterprise operation with output-input contract control. However, enterprises claimed there was still significant government interference in their daily management. This gave rise to a problem with monitoring after enterprises were given autonomy, primarily caused by the separation of ownership and control (Song 2015). The lack of adequate monitoring was attributed to SOEs' poor performance (Huang 1999), and another consequence was that many managers abused their position for personal benefit such as through hiding profits (Chow 2002). This problem became more complicated in the later stages of SOE reform.

\section{Ownership reform through 'grasping the large, letting go of the small', 1992-2003}

The mounting losses of SOEs were a key factor leading to further reforms (Garnaut et al. 2006). Policymakers also saw a need to further develop an institutional base for the expanding market economy (Naughton 2007). The second stage of reform was characterised by ownership transformation (gaizhi), with a focus on the privatisation of SOEs, which began after Deng Xiaoping's tour of southern China in 1992. Gaizhi became an essential element in the government's grand strategy of building 'a modern Chinese enterprise system' for the 'socialist market economy', as set forth by the fourteenth National Congress of the CPC (Song 2015). In line with this target, priority reform steps were taken to develop an institutional framework for the modern enterprise system, based on the Western corporate model. The government issued the Company Law in 1993 and the Competition Law in 1994. The promulgation of specific laws and policies was a substantial step in establishing the regulatory framework for the growing multi-ownership enterprise sector and 
supervisory functions over SOEs (Mattlin 2007). Further, the xiagang ('laid-off) policy, which allowed a large number of workers to be laid-off in the process of ownership change, was carried out (Song 2015; Jefferson 2016). In 1997, the fifteenth National Congress set out the establishment of a social security system (Chow 2002). In the early 1990s, other complementary reforms were carried out, including to fiscal and trade policy. Fiscal system reforms were aimed at setting up a broad tax base and stable central-local government relations. Trade policy reforms unified exchange rates and liberalised the trade regime for enterprises of all ownership types. Moreover, stock markets were established and developed with the securities law enacted in 1999 to support the ownership transformation of SOEs (Naughton 2007). Trade reforms in the 1990s, aimed at China potentially joining the World Trade Organization (WTO), were another significant push factor for the SOE privatisation process (Jefferson 2016).

This process, promoted under the gaizhi policy for ideological and political reasons, took place at a large scale only after the central government adopted its policy of 'grasping the large, letting go of the small' (zhuada fangxiao) in 1995. This policy was formally approved at the fifteenth National Congress in 1997 (Song 2015). About 500 to 1,000 large SOEs were retained, while all other enterprises were restructured through sale or lease. The economic logic behind this policy was that the large firms performed much better than the smaller firms and had greater importance in the economy. While gaizhi served as a euphemism for privatisation, it was carried out in different forms, including through employee shareholding, public offerings (which did not change the state's control rights with internal restructuring measures such as debt-equity swaps), open sales, bankruptcy, leasing and joint ventures with foreign enterprises (Garnaut et al. 2006).

The gaizhi process, combined with related institutional changes, has resulted in the substantial transformation of the SOE sector and associated changes in the nonstate sector. In the period 1995-2003, the number of SOEs declined from 118,000 to about 34,000, and the SOE labour force fell by 44 million people (Song 2015: 191). In the period $1998-2003^{3}$ alone, as shown in Figure 19.1, the number of SOEs decreased by about 23,600 units (Table A19.1), and their labour force dropped by 13 million people (Table A19.2). A group of state-controlled holding firms emerged in the SOE sector as a result of ownership reform. Importantly, gaizhi created an essential channel for transferring state production assets to the nonstate sector, which can be viewed as a reallocation of resources to more productive uses, which contributed to the rapid growth of this sector. In turn, the expansion of

3 Since 1998, China's National Bureau of Statistics (NBS) has reported statistics only for 'above-scale' industrial enterprises, which have annual sales revenue of at least RMB5 million, which is equivalent to about $\$ 600,000$ at the 1998 exchange rate (Jefferson 2016). As a result, there was a sharp drop in the total number of all industrial firms. Therefore, the statistics reported in the tables and figures in this chapter cover the years 1998 to 2017 for the above-scale enterprises only. 
nonstate enterprises supported the privatisation process by absorbing workers laidoff from the restructured SOEs. Moreover, ownership transformation helps both local and central governments to reduce the financial burden caused by poorperforming SOEs_-a win-win situation (Garnaut et al. 2006). As a result, the relative importance of SOEs in total gross output and employment continued to decline, from about 52 per cent and 60 per cent, respectively, to about 44 per cent and 43 per cent between 1998 and 2002 (Figure 19.2). Overall, better resource allocation in the enterprise sector was one outcome of the ownership reform in this period.

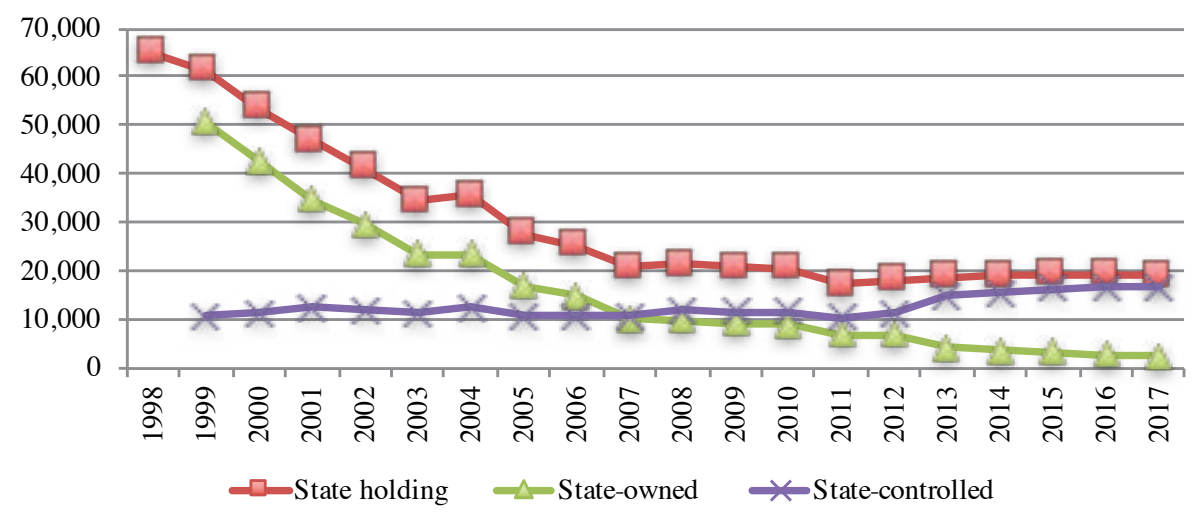

Figure 19.1 Number of state-holding enterprises, 1998-2017

Note: The state-holding enterprises include state-owned and state-controlled enterprises.

Source: CEIC China Database.

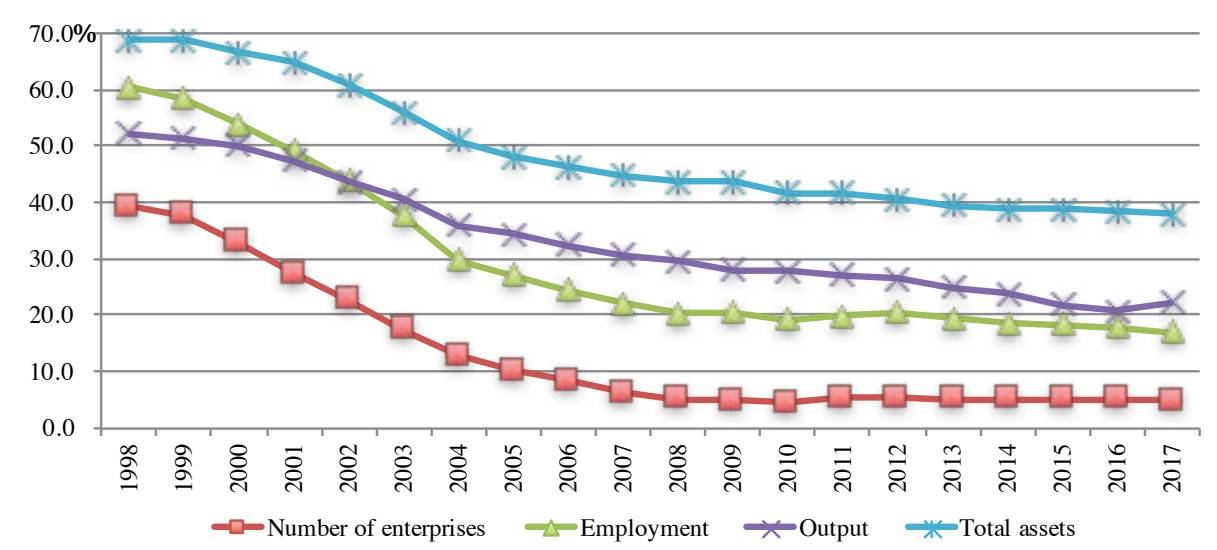

Figure 19.2 Changing relative position of state-holding enterprises, 1998-2017 (per cent)

Note: The state-holding enterprises include state-owned and state-controlled enterprises.

Source: CEIC China Database. 
From the perspective of productivity, privatisation has been successful. Some studies find that ownership reform has improved the productivity of restructured enterprises. Sun and Tong (2003) find that early stage privatisation improved SOEs' earning ability and worker productivity. Garnaut et al. (2006) found evidence that those enterprises undertaking gaizhi improved their efficiency. Ownership transformation also had positive effects on SOEs in terms of financial performance. Song (2015) finds that SOEs' annual profit rate (ROFA) increased from a low of less than 2 per cent in 1997 to more than 6 per cent in 2002. Between 1998 and 2002 (Figures 19.3 and 19.4), the returns on total assets (ROA) and returns on equity (ROE) of the SOEs (including state-controlled shareholding firms) increased significantly and got close to those of private and other nonstate enterprises. As shown in Table A19.3, in the period 1998-2003, state-controlled shareholding enterprises (after gaizhi) appear to perform better as the share of lossmaking firms in this group is about 12 percentage points lower than that in the purely state-owned enterprises.

Although the performance of SOEs improved under extensive restructuring, they still lagged behind private enterprises. Between 1998 and 2003, the share of lossmaking firms in the SOE sector was still very high, at 35-39 per cent-about three to four times higher than that in the private sector (Table A19.3). Therefore, solving the bad debts of SOEs remained a challenging issue for reform. To deal with SOE debt and to support the development of the modern enterprise system, the government undertook banking reforms. Until the late 1990s, state-owned banks dominated China's banking sector. As financial subsidies were the main source of SOEs' losses, as shown above, SOEs dominated the state-owned banks' nonperforming loans (NPLs). In 1995, the Law on the People's Bank of China and the Commercial Bank Law set out the main banking reform programs, providing a framework to impose hardening budget constraints on SOEs. Consequently, four asset management companies under the four largest commercial banks were set up in 1999 to deal with their NPLs to SOEs (Chow 2002).

The weaker financial performance of SOEs remained unresolved, so further reforms were needed. In addition to private and collective firms, the new shareholding enterprises, including the state-controlled ones, necessitated changes to the financial, fiscal and regulatory systems to address the government-enterprise relationship and, more broadly, to support the further development of the institutions of a sophisticated market economy with an open trade regime. 


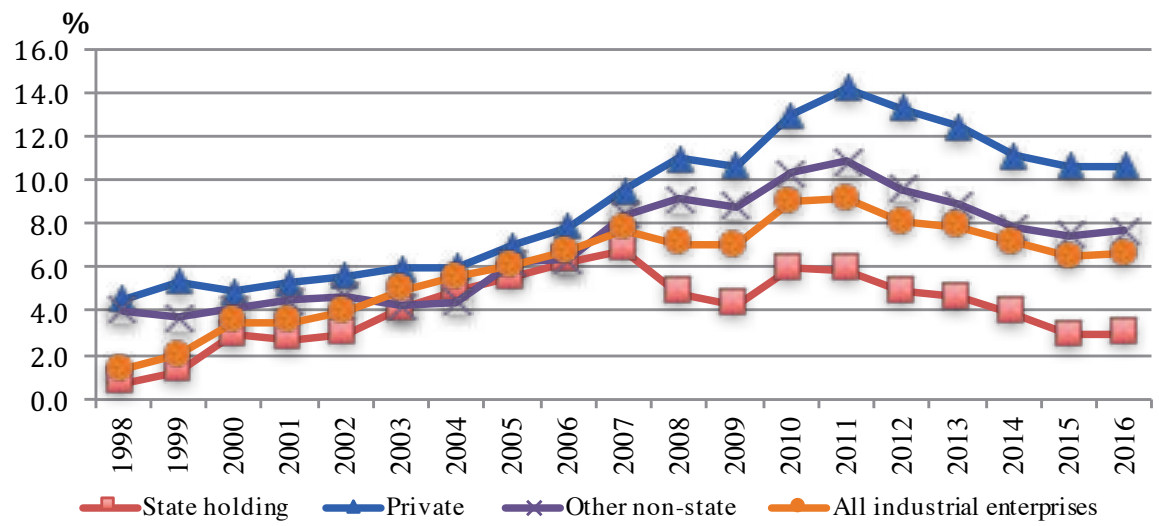

Figure 19.3 Returns on assets of industrial enterprises by ownership type, 1998-2017 (per cent)

Note: The state-holding enterprises include state-owned and state-controlled enterprises.

Source: CEIC China Database.

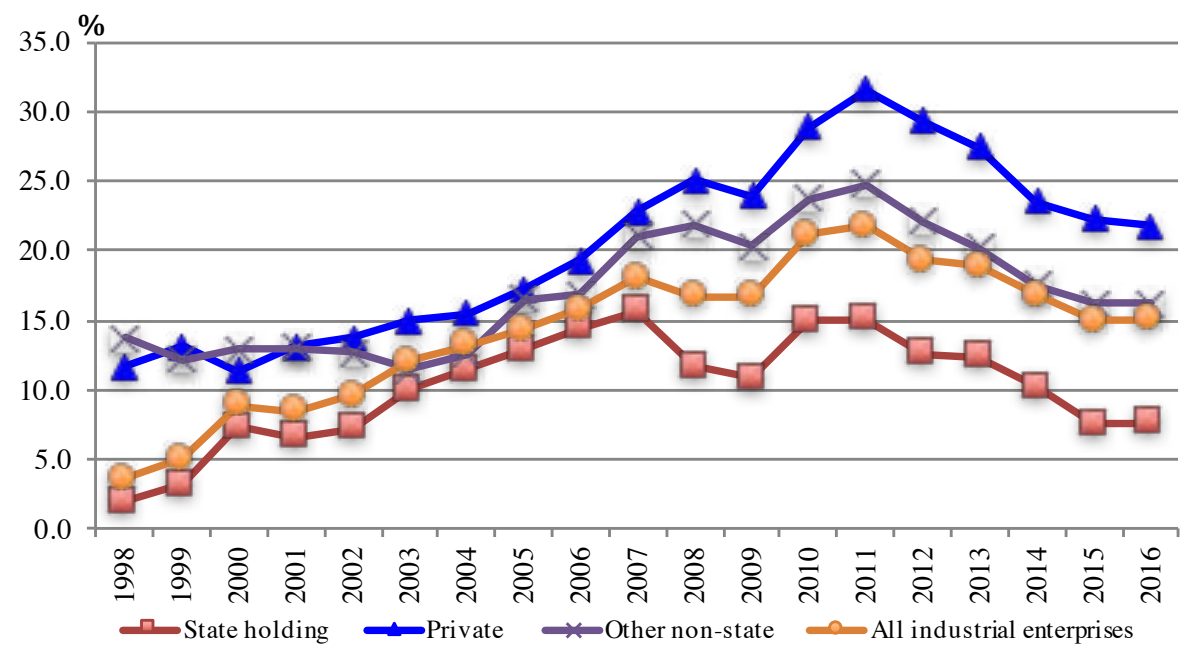

Figure 19.4 Returns on equity of industrial enterprises by ownership type, 1998-2017 (per cent)

Note: The state-holding enterprises include state-owned and state-controlled enterprises.

Source: CEIC China Database. 


\section{Restructuring large SOEs, corporatisation and going global, 2003-13}

Keeping the large SOEs through gaizhi was the first step in building the modern enterprise system. Organisational change was another step in SOE reforms while SOE restructuring under gaizhi continued. With the release of the sixteenth National Congress's guiding principles on the consolidation and development of the publicly owned economy in line with the importance of developing the private economy (Yang 2015), the State-owned Assets Supervision and Administration Commission (SASAC) was established, in March 2003. SASAC itself is under the authority of the State Council. The national-level commission directly supervises central SOEs (yang qi), which are the largest in China's key industries, while indirectly overseeing local SOEs (di fang guo qi), which are under the direct supervision of local governments. The operations of SASAC as the central supervisory agency have had a significant impact on the outcomes of SOE reform.

SASAC's focus was on the preservation and increase of the state-owned assets of SOEs, ${ }^{4}$ while continuing ownership reform to consolidate SOEs. The logic behind this is 'less is more ... By controlling a small fraction of all SOEs, the state can maintain disproportionate control over profits, investments and the national economy' (Mattlin 2007: 45). As a result, the number of SOEs increased and they became huge corporations. From 2003 to 2006, the number of central SOEs under SASAC was reduced from 196 to 159 after consolidation and restructuring (Mattlin 2007). This number continued to fall, to 106, during 2015-16, with the largest enterprises in the industrial sector (Jefferson 2016: 3).

In line with the establishment of SASAC, the Chinese Government emphasised the control of strategic industries. The idea of this sectoral focus had already been put forward in the 'grasping the large, letting go of the small' policy. In September 1999, the fourth plenum of the fifteenth National Congress specified four groups of industries that were to retain SOE dominance: high technology, nonrenewable natural resources, public utilities and infrastructure services, and national security (Broadman 2002). In 2006, the State Council suggested a more specific list of industry groups and ownership goals, a detailed description of which is shown in Table 19.1.5

4 The supervision powers of SASAC are listed on its official website (en.sasac.gov.cn/n1408028/n1408521/index. html).

5 This list is a reference source as the industries and ownership goals included may vary over time due to different policy directions. 
Table 19.1 Goals of ownership change by industry

\begin{tabular}{|l|l|l|}
\hline Industry group & Industries included & Ownership goal \\
\hline Strategic and key industries & $\begin{array}{l}\text { Defence, power generation } \\
\text { and distribution, oil } \\
\text { and petrochemicals, } \\
\text { telecommunication, coal, } \\
\text { civil aviation, shipping }\end{array}$ & $\begin{array}{l}\text { Maintaining 100 per cent state } \\
\text { ownership or absolute control; } \\
\text { increasing state-owned assets } \\
\text { in these industries }\end{array}$ \\
\hline Basic and pillar industries & $\begin{array}{l}\text { Machinery, automobiles, } \\
\text { IT, construction, steel, base } \\
\text { metals, chemicals, land } \\
\text { surveying, research and } \\
\text { development }\end{array}$ & $\begin{array}{l}\text { Absolute or conditional relative } \\
\text { controlling stake; enhancing the } \\
\text { influence of state ownership even } \\
\text { as the ownership share is reduced, } \\
\text { where appropriate }\end{array}$ \\
\hline Other industries & $\begin{array}{l}\text { Trading, investment, medicine, } \\
\text { construction materials, } \\
\text { geological exploration }\end{array}$ & $\begin{array}{l}\text { Maintaining necessary influence } \\
\text { by controlling stakes in key } \\
\text { companies; in non-key companies, } \\
\text { state ownership will be reduced }\end{array}$ \\
\hline
\end{tabular}

Source: Extracted from Mattlin (2007: Table 1, p. 16).

The government has used a variety of industrial policy measures to allocate resources, especially financial resources to SOEs in the strategic and pillar industries. The most common action is the use of administrative, technical or regulatory entry barriers (World Bank and DRC 2013). SOEs were also provided with preferential access to loans or credit through the banking sector, which is dominated by the state-owned banks (Song et al. 2011), and better access to land. These measures, in the context of marketisation, created substantial economic rents (Chu and Song 2015), which were accrued primarily to SOEs and provided them with a significant amount of earnings and savings with which to expand. Moreover, SASAC and other government agencies supported the expansion of SOEs through two additional avenues: public listings on domestic and international stock exchanges and international mergers and acquisitions (M\&As). Notably, foreign M\&As were a vital strategy adopted by SOEs to expand under the 'go global' policy put forward by the government in the early 2000s, with the primary objective of obtaining secure access to critical raw materials, resources and energy (Song et al. 2011). As a result, many SOEs had become among the largest corporations globally. In 2014, some 98 SOEs were on the Fortune Global 500 list, with their sales concentrated in energy, finance, telecommunication, engineering and construction and motor vehicle and parts industries (Jefferson 2016: 5).

Overall, the continuing SOE restructuring process under SASAC resulted in a substantial increase in the average size of SOEs. As shown in Table A19.1, the number of SOEs decreased significantly, from 34,280 in 2003 to 17,851 in 2012. A contributor to this drop in the state-holding enterprises was the reduction in the number of purely state-owned enterprises, as the number of state-controlled shareholding enterprises remained steady around 11,000 over the period 2003-12. This trend suggests that very few purely SOEs under restructuring were transformed 
into state-controlled shareholding enterprises. Moreover, between 2003 and 2012, the total asset value of purely SOEs and state-controlled enterprises increased substantially and consistently (Figure A19.1). Similarly, their revenue (output) value grew considerably, except during the Global Financial Crisis (GFC) in 2008-09 (Figure A19.2). These trends are consistent with SASAC's measures to restructure and consolidate SOEs, primarily through M\&As. As a result, all became much larger in terms of total assets and sales output, as shown in Figures A19.3 and A19.4. The average size of SOEs in terms of total assets increased from RMB276 million in 2003 to RMB1.75 billion in 2012. Their average output value grew from RMB170 million to RMB1.37 billion ${ }^{6}$ in 2012. The size of SOEs was increasing and they became much more significant than nonstate, foreign and HMT-funded enterprises over the period 2003-12. On average, the state-controlled shareholding enterprises were larger than the purely SOEs.

SOEs' contribution to the industrial sector continued to decrease. The state sector's share in the total number of firms drastically declined between 2003 and 2007, to a low level of about 5 per cent. Following a similar trend, SOEs' shares in total industrial employment and sales were still significant, at about 20 per cent and 25 per cent, respectively, in 2013. In contrast, in 2013, SOEs still held up to 40 per cent of total industrial assets, although this had declined from 56 per cent in 2003. The trend of SOEs' shares in the number of firms and total employment, sales and assets shows that substantial SOE restructuring took place between 2003 and 2007, and then slowed until 2013. However, this did not happen with the total value of assets, sales output and average firm size.

Several studies find that SOE restructuring continued to have significant positive effects on enterprise productivity in the period 2003-07 following SOE reforms in 1998-2003. Brandt and Zhu (2010) find that, in the period 1998-2007, SOEs' TFP growth was substantially higher than that in the period 1988-98, and even higher than that of nonstate enterprises. Hsieh and Song (2015) also find a significant increase in SOEs' TFP growth, resulting from restructuring during the period 1998-2007. In terms of financial performance, the SOE sector also improved substantially, and came close to private and other nonstate enterprises during the period 2003-07. As shown in Figures 19.3 and 19.4, the ROA of SOEs rose from about 4 per cent to 7 per cent, while the ROA of private enterprises increased from 6 per cent to 9.5 per cent-indicating a gap of 2-2.5 per cent. The ROE of SOEs grew from 11.5 per cent to 16 per cent, while the ROE of private enterprises increased from 15 per cent to 21 per cent-indicating a gap of 4-5 per cent.

6 Specific numbers were calculated using data obtained from the CEIC China Database. 
SOEs' financial performance deteriorated noticeably during the period 2007-13, when there was rapid growth in the average size of assets and output. As shown in Figures 19.3 and 19.4, both the ROA and the ROE of SOEs dropped during 2008-09 and picked up again during 2010-11, before falling in 2012-13. This trend reflects the effects of the GFC and the impact of the government's stimulus policy. Private and other nonstate enterprises experienced a similar trend in their financial performance; however, the gap in financial performance between SOEs and private enterprises was increasingly larger. The gap in ROA and ROE increased to 5-8 per cent and 11-15 per cent, respectively. SOEs' productivity and financial performance would be lower than private enterprises if the economic rents generated by the government's market restrictions and control were separated from profits. This trend in the performance gap between SOEs and private enterprises is consistent with the difference in the percentage of lossmaking firms in the two groups. During the period 2003-13, the portion of lossmaking SOEs was in the range of 20-38 per cent, while that of private enterprises was between 6 and 15 per cent, as shown in Table A19.3.

The worsening performance of the whole SOE sector can be attributed to certain factors of SOEs' operation and governance. The first issue is the complex mix of policy and commercial objectives assigned to SOEs. There is a popular perception that, as well as commercial objectives, SOEs, as the backbone of the socialist market economy, have been designated to carry out public policy functions and obtain government objectives such as macroeconomic stabilisation, maintaining social stability and crisis response. For example, one public purpose of the SOEs can be seen in SASAC's guidelines on SOE corporate governance: SOEs are expected 'to promote the socialist harmonious society and ... to thoroughly implement China's new ideas about economic development, social progress, and environmental protection' (Jefferson 2016: 5). Such activities are often not profitable, as their output is a public good. SOEs' lower returns also result from problems of overstaffing, particularly due to consolidation, as social security protection is a political and functional feature of the SOEs. SOEs internalise such losses in exchange for their privileged access to government-controlled resources, especially bank lending and land. Also, the government collected no dividends from profitable SOEs before 2007 (Mattlin 2007) and few dividends (5-15 per cent) after 2007 (Milhaupt and Zheng 2015). Those support measures have significantly exacerbated the SOEs' soft budget constraint problem. The soft budget constraint has been an ongoing problem, as is evident in the SOEs' NPL phenomenon. Jefferson (2016: 6) observes that there is a 'chronic tendency of China's political economy to replenish the diminished resources of the SOEs ... through lending from the banking sector, primarily the four large commercial banks, which are themselves state-owned'. 
The second issue is the weak oversight of SOE managers and weak corporate governance, mostly in the form of the principal-agent problem since autonomy was given to SOE managers under the contract responsibility system. With the policy of SOEs 'growing large and going global' after consolidation and restructuring, new dimensions of this issue emerged, with significant negative consequences on SOEs' performance. With authority delegated from the government, enterprise managers or corporate executives can make decisions on enterprise operation, investment, marketing, input supplies and contractor selection. However, there are challenges in monitoring the accountability of enterprise managers' business decisions for several reasons. First, despite the government's various personnel control measures, it is difficult and costly for it, and particularly SASAC, to keep senior SOE managers or executives in check due to their insider control and delegated authority (Milhaupt and Zheng 2015). Second, SOE managers possess significant personal power based on their party and administrative roles and personal social networks (Leutert 2016). And third, the boards of directors in state-controlled shareholding enterprises are influenced or dominated by the relevant government agency or SOE representatives, often including SOE managers themselves, while independent directors are a minority. As a result, SOE managers have been able to make business decisions for their benefit at the expense of their enterprises. The personal power of managers and the economic importance of large SOEs, especially central SOEs, have made them powerful interest groups holding sway over critical sectors of the economy, which can affect government policies (Zhang and Freestone 2013). The most evident result is rampant corruption and misconduct among SOE leaders. For example, The Diplomat reported in 2014 that the National Audit Office had uncovered 35 cases of bribery and embezzlement and managers in 11 inspected SOEs had spent company funds on luxury goods and entertainment (Hsu 2014). Another example is a report in the South China Morning Post that between November 2012 and April 2015, some 124 top officials in SOEs_-most working in energy, infrastructure and telecoms-were facing corruption charges (Meng 2015).

Another consequence related to the SOE soft budget constraint is overinvestment, because as well as having easy access to funding sources, many SOEs also had considerable corporate savings from retained profits due to small dividend payments. Moreover, many local governments encouraged local SOEs to undertake large investment projects in pursuit of regional economic growth (Mattlin 2007). These have contributed to problems of overcapacity, large debts and 'zombie' firms, particularly in steel, coal and metal industries (Naughton 2016). At a sectoral level, lower efficiency and increased competitive pressures from private enterprises have seen SOEs' output share shrink while still holding a dominant share in some pillar and strategic industries. Such falls in output shares did not happen in national defence and other key sectors such as coal, ferrous metal, the production and supply of water and gas, metal ores, transport equipment, machinery and chemical products (Zhang and Freestone 2013). The imbalance between SOEs' output shares and their asset holdings suggests the removal of entry barriers, if any, and SOE 
ownership transformation would enhance the efficiency and output growth of these industries. Therefore, the issues with the performance of the SOEs discussed above are considered unfinished tasks of the most recent reform period.

\section{Renewed mixed-ownership reform, corporate governance and challenges ahead, 2013 - present}

The decision of the third plenum of the eighteenth National Congress in November 2013 marked the new wave of SOE reforms. The decision laid out important directions for reform to address the key issues of SOE governance and operation structure, including: 1) defining the functions of SOEs to determine levels of state ownership and control; 2) promoting mixed ownership; and 3) shifting from asset management to capital management and increasing dividend payments for social security funds (Yang 2015: 59). However, until 2015, substantial steps to implement the new SOE reform measures were carried out only after the guiding opinions and more than 10 regulations were issued (Naughton 2016: 65).

The State Council's initiative for developing mixed ownership in the guideline issued in September 2015 applied specific sectoral policies. For competitive sectors, the direction was to 'steadily promote the mixed ownership of SOEs and make sure both state capital and non-state capital engage in the operation of the relevant SOEs', while for strategic sectors, 'SOEs in the relevant sectors should remain statecontrolled, but share-holdings of non-state parties are encouraged' (State Council 2015). A significant example is the share sale plan for China Unicom, China's second-largest telecom carrier. It was announced in August 2017 that it would sell US $\$ 11.7$ billion in shares worth 35 per cent of its Shanghai-listed unit to a group of private and state investors, including tech giants Alibaba, Baidu, Tecent and JD.Com, and a sizeable state-owned insurance company, China Life Insurance Company. The telecommunications sector has long been a strategic sector under strict state control. This giant stride of partial privatisation will see the stake in the listed units held by Unicom's unlisted, wholly state-owned parent drop from 63 per cent to 37 per cent following the deal (Bloomberg News 2017). Private investors will also gain power over the daily operations of China Unicom, and will be able to appoint four members of the board of directors, which will also have six state shareholders and five independent members. Moreover, this initiative also encourages nonstate enterprises to enter parts of the strategic sectors that are unrelated to national security. For example, in November 2015, PetroChina restructured its natural gas division and planned to sell its stake in the natural gas network to China Reform Holdings, an agent of SASAC. The natural gas network would thus be established as an independent SOE to allow private and foreign capital to engage in the supply of natural gas (Hornby 2015). 
It appears the Chinese Government has chosen the 'picking the winner' approach to mixed-ownership reform, with leading and large private companies that have emerged through market competition able to take a stake in large SOEs in previously restricted sectors. The process of partial privatisation has been carried out by a more market-determined process through stock markets, reducing concerns in previous stages of privatisation about corruption in selling state assets at low prices. It is a promising trend that more private capital is being allowed into strategic and pillar industries as more competition is introduced and private firms' technical, management and strategy expertise is utilised. At the same time, state-owned capital investment and operation companies under SASAC at the central and local levels have been set up to invest in both state and private enterprises. The focus of their investment are high-tech and new industries (for example, information technology, biopharmaceuticals, smart manufacturing, new energy and new materials) as part of the government's restructuring efforts to foster technological innovation for the productivity-driven growth model (Naughton 2016: 67).

In the 2015 guideline on deepening SOE reforms, for the first time, SOEs were divided into two categories: a public category (gongyilei) and a commercial category (shangyelei) (Central Committee of the CPC and State Council 2015). This classification creates a dual-track approach to evaluating the performance of SOEs. Specifically, this new guideline stipulates that public firms will be assessed by their cost control ability, the quality of their goods and services and the stability and efficiency of their operations. Political rather than market logic will, therefore, remain dominant in SOEs in the public class. In contrast, increasing market competition and improving financial performance will be the priorities for SOEs designated as commercial. While all this looks like a step towards a new round of marketisation in SOEs, these documents stress that SOEs should remain party controlled. SOEs will still serve political goals such as fostering indigenous innovation, supporting social stability and promoting economic initiatives abroad such as the Belt and Road Initiative (BRI), regardless of the category to which they belong. The stake in SOEs held by large private investors might not grant them real power to influence strategy for these enterprises. In practice, top SOE managers and chairpersons of boards of directors are appointed by SASAC and approved by the personnel bureau of the CPC, which means even though China Unicom has four private investors as board members, the Communist Party may still override their power. Nevertheless, the participation of private power on the boards of directors, at least partially, brings management experience and economic resources from the private sector, which may have potential benefits for the efficiency and financial performance of SOEs.

Another point of the 2015 guideline was the call for ongoing government-directed mergers to make SOEs larger and stronger, which has long been a stated goal. The logic behind government-directed mergers is to eliminate unprofitable SOEs without sacrificing employment, to end price wars among SOEs and embody the 
strategy of creating 'national champions' (Leutert 2016). However, the governmentdirected merger is a double-edged sword. Domestically, it does end price wars, overproduction of products and overlapping investment between SOEs in the same sector, but it also creates administrative monopolies that lead to stronger pricing powers and less external pressure to improve quality and services, which is an indirect subsidy to SOEs. Internationally, again, it does stop overseas price wars among SOEs and increases their international competitiveness in the short run, but the global competitiveness of SOEs might decline in the long term due to less pressure in the domestic market leading to fewer incentives to improve product quality and operational efficiency. The creation of overly large SOEs may also exaggerate the ills of these organisations-inefficient operations, communication gaps and weak oversight. Other potential problems include the creation of redundant staff and departments or duelling executive teams (Leutert 2016).

Nevertheless, to serve the BRI and 'going out' initiatives of SOEs, mergers to create large 'national champions' will help provide sufficient economic resources for overseas M\&As and research and development (R\&D). The mergers will also help avoid the loss of financial resources due to price wars among SOEs in the international market. One significant example in recent years is the merger of China CSR Corp and China CNR, the world's two largest manufacturers of rail rolling stock, with combined total assets of RMB299.7 billion (US\$48.3 billion in 2014 prices), in 2015. Before 2000, CSR and CNR belonged to one company, China National Railway Locomotive \& Rolling Stock Industry Corporation, and, in September 2000, the State Council approved the splitting of this company to promote domestic competition in locomotive and rolling stock manufacturing. However, in recent years, the revenue of these two large SOEs has relied more and more on the international market, and the price war between them has been a problem. In 2011, they fought a price war for a Turkish contract, which eventually went to a South Korean firm. In 2013, when they were competing for high-speed train contracts in Argentina, CSR proposed a quote that was far below that of CNR and far below the manufacturing costs. This led to the Argentines distrusting the quality of Chinese high-speed trains (Financial Times 2014) and the now-defunct Ministry of Railways openly criticising the incident. The merger put a full stop to the price war between CNR and CSR, which increased the competitiveness of Chinese high-speed trains in the global market. The Chinese Government has regarded the merger of CNR and CSR into China Railway Materials (CRM) as a successful case for the merger of other large SOEs. Many other large SOEs followed suit, such as the merger of Shanghai Baosteel Group and Wuhan Iron \& Steel, which started in 2016, and other potential mergers within machine manufacturing, steel manufacturing, electricity and coal-related industries that undertake a substantial proportion of economic activities overseas. 
The 2015 guideline also mentions personnel management reforms in SOEs. Traditionally, SOE managers are appointed by SASAC and enjoy a bureaucratic rank similar to government officials, which often leads to bureaucratism and low efficiency. The recent reform aims to establish a dual track for SOE personnel management. Managers belonging to the bureaucratic system enjoy lifelong job security but sacrifice a market-based salary, while managers outside the bureaucratic system enjoy market-based wages, but their jobs are contract-based with specific terms and subject to annual evaluation. This dual-track system still has a long way to go. The pilot program included only five SOEs in 2014, while in 2016 another three to five SOEs were to join this program (Ng 2016).

Following the 2015 guideline, a document issued by the State Council in April 2017 revealed some of the targets for recent SOE reforms, which aim to build a modern enterprise system while strengthening Communist Party control (State Council 2017). According to this document, a modern enterprise system was to be established in SOEs by the end of 2017. By the end of 2020, the role of the $\mathrm{CPC}$ in the corporate governance of SOEs should be strengthened, and company charters should exert a fundamental role over corporate governance. For wholly state-owned enterprises, external directors should be the majority on the boards of directors. Corporate governance should help entrepreneurs exert their full potential and nurture competent board chairpeople, professional managers and directors. Anticorruption measures will continue to be applied alongside reform, and management should be significantly improved as a result of changes to corporate governance. SOEs should operate independently following the laws of a market economy and enterprise development.

The renewed reform measures have had specific effects on the structure of the SOE sector. The number of purely SOEs continued to decline to 2017. In contrast, the number of state-controlled shareholding enterprises increased dramatically in the same period. These trends show that mixed-ownership reform measures have continued with the transformation of purely SOEs into state-controlled shareholding firms. In contrast with the shrinking number of firms, the size of purely SOEs increased sharply during the period 2015-17. This trend shows the significant impact of renewed ownership reform, with continued consolidation and new investment. State-controlled shareholding enterprises increased their total assets. However, the financial performance of SOEs in terms of ROA and ROE did not show any improvement, and their gap with private enterprises remained the same during 2013-16 (Figures A19.3 and A19.4). This situation suggests that while more radical reform measures have been taken recently, it will be some time before their impact on the overall performance of SOEs is evident. 


\section{Concluding remarks}

After 40 years, market-oriented reforms have significantly transformed China's SOE sector. While now having a minor share in total numbers, employment and output, the SOE sector remains significant in the economy, accounting for nearly 40 per cent of total industrial assets in 2017, and has a dominant share in the banking and financial and other strategic sectors. The SOE sector has been transformed into a modern corporate sector with many large and globally operated corporations, diversified ownership and complex organisational and operational structures. The transformation of SOEs has been the key to the rise of the vibrant and rapidly growing nonstate enterprise sector. Under China's market-oriented transition, without a robust regulatory framework to capture and allocate economic rents, the use of SOEs in key industries and factor markets has helped the Chinese Government to mobilise resources for infrastructure investments to achieve the high growth rates seen in the reform period. SOEs have also played a vital role in meeting the government's policy objectives, such as macroeconomic and social stability and advancing national interests.

While reforms haveled to improvements in the productivity and financial performance of many SOEs, the overall performance of the SOE sector has been declining and lagging behind private and other nonstate enterprises in the past 10 years. The current reforms have been targeted at the core issues of SOE operation and governance, including their function-based classification, ownership diversification, sectoral competition and entry barriers, autonomy and monitoring and corporate governance. With the most recent radical reform measures being implemented to address inherent problems in SOEs, their effects are yet to materialise and remain contingent on other market-oriented reforms.

It is time to reduce the number of lossmaking SOEs as their share in the state sector is still significantly higher than in the nonstate sector. This is consistent with the government's ongoing supply-side reforms to reduce excess capacity, deleverage and support industrial restructuring. Governments at both central and local levels have overseen the development of social security funds to help redundant workers. An essential source of funding could be the partial transfer of dividend payments from profitable SOEs, which may require additional institutional arrangements.

Further ownership reform of SOEs in pillar and strategic industries is conducive to efficiency and productivity, and state capital has also been invested in private firms in new industries. This demonstrates the growing role of the private sector in SOEdominated and monopolistic industries. The definition of national interests has been changed to include leading private firms in strategic and new industries. It is reasonable to allow more private enterprise participation in providing public goods such as infrastructure development and services as long as transparent government 
procurement frameworks are adopted to ensure fair competition and avoid corrupt practices. With the increasing participation of private enterprise, it is also essential to strengthen the enforcement of tax laws and regulations on key inputs, resources and services markets to regulate economic rents for the public interest.

There is a need for the functions of current reforms to be focused more on the regulatory realm. Other market-supporting legal and regulatory changes should be reinforced in areas such as equal access to land and credit to reduce the soft budget constraint, transparent procedures for government funding for R\&D and strengthening financial market regulations. With challenges to the reform of corporate governance in the largest SOEs, specific laws governing their operations and their relationships with government agencies are an option. This would help increase the transparency of their business activities in domestic as well as global markets. Caution needs to be exercised to avoid excessive party control, which could discourage the entry of private capital and interfere with enterprises' commercial operations.

China's SOEs continue to play a significant role in several strategic industries, including new sources of energy, telecommunications and information technology, automation, transport equipment (such as automobiles, aviation, shipbuilding and high-speed railways), new materials, space technologies, construction materials and infrastructure development. The government has also called on SOEs to play a critical role in achieving the goals of the 'Made in China 2025' policy, which aims to build high-end manufacturing industries across all key industrial sectors.

The new measures for market opening with further tariff reduction and market entry, announced by the Chinese Government in 2018, will accelerate the pace of SOE reform as the sector faces increased competition to make necessary adjustments. The success of SOE reform holds the key to deepening China's supply-side reform, which, if successful, will raise the prospect of more robust growth in China during the next phase of its development.

\section{References}

Bai, C. E., Lu, J. and Tao, Z. (2006), The multitask theory of state enterprise reform: Empirical evidence from China, The American Economic Review 96(2): 353-7. doi.org/10.1257/000282806777212125.

Bloomberg News (2017), Alibaba to China Life join Unicom's \$11.7 billion stake sale, Bloomberg News, 16 August. Available from: www.bloomberg.com/ news/articles/2017-08-16/unicom-to-raise-11-7-billion-via-stock-sale-to-alibabaothers. 
Brandt, L. and Zhu, X. D. (2010), Accounting for China's growth, IZA Discussion Paper No. 4764, February, Bonn: Institute for the Study of Labor. Available from: ftp.iza.org/dp4764.pdf.

Broadman, G. (2002), The business(es) of the Chinese state, The World Economy 24(7): 849-75. doi.org/10.1111/1467-9701.00386.

Central Committee of the Communist Party of China (CPC) and State Council (2015), Guideline on Deepening SOE Reform, 24 August, Beijing: CPC Central Committee.

Chow, G. (2002), China's Economic Transformation, Malden, MA: Blackwell.

Chu, S. N. and Song, L. (2015), Promoting private entrepreneurship for deepening market reform in China: A resource allocation perspective, China \& World Economy 23(1): 47-77. doi.org/10.1111/cwe.12099.

Financial Times (2014), The merger of CSR and CNR cannot solve the fundamental problem, [in Chinese], Financial Times, 26 December. Available from: www. ftchinese.com/story/001059858.

Garnaut, R., Song, L. and Yao, Y. (2006), Impact and significance of state-owned enterprise restructuring in China, The China Journal 55: 35-63.

Hornby, L. (2015), PetroChina restructures gas unit, Financial Times, 26 November.

Hsieh, C. and Song, Z. (2015), Grasp the large, let go of the small: The transformation of the state sector in China, NBER Working Paper No. 21006, Cambridge, MA: National Bureau of Economic Research.

Hsu, S. (2014), China's changing state-owned enterprise landscape: To maintain economic growth, SOE reform will need to be meaningful, The Diplomat, 25 June. Available from: thediplomat.com/2014/06/chinas-changing-stateowned-enterprise-landscape/.

Huang, Y. (1999), State-owned enterprise reform, in R. Garnaut and L. Song (eds), China: Twenty years of reform, Canberra: Asia Pacific Press.

Jefferson, G. (2016), State-owned enterprise in China: Reform, performance, and prospects, Working Paper No. 109R, Waltham, MA: Brandeis University, Department of Economics and International Business School.

Jefferson, G. and Rawski, T. G. (1994), How industrial reform worked in China: The role of innovation, competition and property rights, in Proceedings of the World Bank Annual Conference on Development Economics, Washington, DC: The World Bank. doi.org/10.1093/wber/8.suppl_1.129. 
Jefferson, G. and Su, J. (2006), Privatisation and restructuring in China: Evidence from shareholding ownership, 1995-2001, Journal of Comparative Economics 34: 146-66.

Kornai, J. (1986), The soft-budget constraint, Kyklos 39(1): 3-30. doi.org/10.1111/ j.1467-6435.1986.tb01252.x.

Kornai, J., Maskin, E. and Roland, G. (2003), Understanding the soft-budget constraint, Journal of Economic Literature XLI: 1095-136. doi.org/10.1257/ jel.41.4.1095.

Leutert, W. (2016), Challenges ahead in China's reform of state-owned enterprises, Asia Policy (21)(January): 83-99.

Mattlin, M. (2007), The Chinese Government's new approach to ownership and financial control of strategic state-owned enterprises, BOFIT Discussion Paper No. 10/2007, 13 April, Helsinki: Bank of Finland Institute for Economies in Transition. Available from: ssrn.com/abstract $=1001617$.

McMillan, J. and Naughton, B. (1992), How to reform a planned economy: Lessons from China, Oxford Review of Economic Policy 8(1): 130-43. doi.org/10.1093/ oxrep/8.1.130.

Meng, A. (2015), A quarter of Chinese SOE executives investigated for corruption work in energy sector, South China Morning Post, 28 April. Available from: www. scmp.com/news/china/policies-politics/article/1778702/quarter-chinese-soeexecutives-investigated-corruption.

Milhaupt, C. J. and Zheng, W. (2015), Beyond ownership: State capitalism and the Chinese firm, The Georgetown Law Journal 103(665). Available from: scholarship. law.ufl.edu/facultypub/696.

Naughton, B. (2007), The Chinese Economy: Transitions and growth, Cambridge, MA: MIT Press.

Naughton, B. (2016), Restructuring and reform: China 2016, Paper presented at Structural Change in China: Implications for Australia and the World, Reserve Bank of Australia, Sydney.

$\mathrm{Ng}$, J. (2016), China plans to expand the pilot program of market-based SOEs managers recruitment, [in Chinese], Financial Times, 4 July. Available from: www.ftchinese.com/story/001068296\#adchannelID $=2000$.

Rawski, T. G. (1994), Chinese industrial reform: Accomplishments, prospects, and implications, The American Economic Review 84(2): 271-5. 
Song, L. (2015), State and non-state in China's economic transition, in G. C. Chow and D. Perkins (eds), Routledge Handbook of the Chinese Economy, New York: Routledge.

Song, L., Yang, J. and Zhang, Y. (2011), State-owned enterprises' outward direct investment and the structural reform in China, China \& World Economy 19(4): $38-53$.

State Council (2015), Guideline on Developing Mixed Ownership in SOEs, Document No. 54, 24 September, Beijing: General Office of the State Council.

State Council (2017), Instructions on Further Promoting Modern Corporate Governance in SOEs, Document No. 36, Beijing: General Office of the State Council.

Sun, Q. and Tong, W. H. S. (2003), China share issue privatisation: The extent of its success, Journal of Financial Economics 70: 183-222. doi.org/10.1016/ S0304-405X(03)00145-4.

World Bank and Development Research Center of the State Council (DRC) (2013), China, 2030, Washington, DC: The World Bank.

Yang, W. (2015), The new round of reform of state-owned enterprises, Journal of Entrepreneurship in Emerging Economies 7(1): 55-66. doi.org/10.1108/JEEE10-2014-0036.

Zhang, D. and Freestone, O. (2013), China's unfinished state-owned enterprise reforms, Economic Roundup No. 2, 6 December, Canberra: The Treasury, Government of Australia. Available from: treasury.gov.au/publication/economicroundup-issue-2-2013-2/.

Zhang, W. (2009), The 'China model' of SOE reform and its challenges, China Economist 4(2): 16. Available from: ssrn.com/abstract=1544336. 


\section{Appendix 19.1}

Table A19.1 Number of enterprises by ownership type, 1998-2017 (unit)

\begin{tabular}{|l|r|r|r|r|r|}
\hline Year & State-holding & State-owned & State-controlled & Private & Total \\
\hline 1998 & 64,737 & & & 10,667 & 165,080 \\
\hline 1999 & 61,301 & 50,651 & 10,650 & 14,601 & 162,033 \\
\hline 2000 & 53,489 & 42,426 & 11,063 & 22,128 & 162,885 \\
\hline 2001 & 46,767 & 34,530 & 12,237 & 36,218 & 171,256 \\
\hline 2002 & 41,125 & 29,449 & 11,676 & 49,176 & 181,557 \\
\hline 2003 & 34,280 & 23,228 & 11,052 & 67,607 & 196,222 \\
\hline 2004 & 35,597 & 23,417 & 12,180 & 119,357 & 276,474 \\
\hline 2005 & 27,477 & 16,824 & 10,653 & 123,820 & 271,835 \\
\hline 2006 & 24,961 & 14,555 & 10,406 & 149,736 & 301,961 \\
\hline 2007 & 20,680 & 10,074 & 10,606 & 177,080 & 336,768 \\
\hline 2008 & 21,313 & 9,682 & 11,631 & 245,850 & 426,113 \\
\hline 2009 & 20,510 & 9,105 & 11,405 & 256,031 & 434,364 \\
\hline 2010 & 20,253 & 8,726 & 11,527 & 273,259 & 452,872 \\
\hline 2011 & 17,052 & 6,707 & 10,345 & 180,612 & 325,609 \\
\hline 2012 & 17,851 & 6,770 & 11,081 & 189,289 & 343,769 \\
\hline 2013 & 18,574 & 3,957 & 14,617 & 208,409 & 369,813 \\
\hline 2014 & 18,808 & 3,450 & 15,358 & 213,789 & 377,888 \\
\hline 2015 & 19,273 & 3,234 & 16,039 & 216,506 & 383,148 \\
\hline 2016 & 19,022 & 2,459 & 16,563 & 214,309 & 378,599 \\
\hline 2017 & 18,806 & 2,372 & 16,434 & 222,473 & 385,369 \\
\hline
\end{tabular}

Note: The state-holding enterprises include state-owned and state-controlled enterprises.

Source: CEIC China Database.

Table A19.2 Industrial employment by ownership type, 1998-2017 (thousand people)

\begin{tabular}{|l|r|r|r|}
\hline Year & State-holding & Private & Total industrial sector \\
\hline 1998 & $37,477.8$ & $1,608.0$ & $61,958.1$ \\
\hline 1999 & $33,945.8$ & $2,290.6$ & $58,050.5$ \\
\hline 2000 & $29,952.5$ & $3,464.2$ & $55,593.6$ \\
\hline 2001 & $26,751.1$ & $5,415.2$ & $54,408.4$ \\
\hline 2002 & $24,236.3$ & $7,329.0$ & $55,200.6$ \\
\hline 2003 & $21,628.7$ & $10,276.1$ & $57,485.7$ \\
\hline 2004 & $19,732.0$ & $15,154.3$ & $66,220.9$ \\
\hline 2005 & $18,748.5$ & $16,920.6$ & $68,959.6$ \\
\hline 2006 & $18,040.0$ & $19,710.1$ & $73,584.3$ \\
\hline 2007 & $17,429.9$ & $22,529.1$ & $78,752.0$ \\
\hline
\end{tabular}


19. State-owned enterprise reform in China

\begin{tabular}{|l|r|r|r|}
\hline Year & State-holding & Private & Total industrial sector \\
\hline 2008 & $17,941.0$ & $28,718.9$ & $88,376.3$ \\
\hline 2009 & $18,033.7$ & $29,738.4$ & $88,312.2$ \\
\hline 2010 & $18,363.4$ & $33,120.6$ & $95,447.1$ \\
\hline 2011 & $18,119.8$ & $29,564.1$ & $91,672.9$ \\
\hline 2012 & $18,927.7$ & $31,213.0$ & $92,729.4$ \\
\hline 2013 & $18,894.9$ & $33,593.9$ & $97,914.6$ \\
\hline 2014 & $18,426.7$ & $35,053.2$ & $99,772.1$ \\
\hline 2015 & $17,778.3$ & $34,639.8$ & $97,750.2$ \\
\hline 2016 & $16,959.3$ & $33,977.6$ & $94,755.7$ \\
\hline 2017 & $14,954.0$ & $32,711.0$ & $88,594.0$ \\
\hline
\end{tabular}

Note: The state-holding enterprises include state-owned and state-controlled enterprises.

Source: CEIC China Database.

Table A19.3 Share of lossmaking enterprises by ownership type, 1999-2017 (per cent)

\begin{tabular}{|l|r|r|r|r|r|}
\hline Year & State-holding & State-owned & State-controlled & Private & Total \\
\hline 1999 & 39.2 & 41.1 & 29.9 & 7.9 & 27.3 \\
\hline 2000 & 34.1 & 36.4 & 25.3 & 13.8 & 23.4 \\
\hline 2001 & 36.0 & 39.0 & 27.7 & 13.4 & 23.0 \\
\hline 2002 & 36.1 & 39.4 & 28.0 & 11.9 & 20.8 \\
\hline 2003 & 35.2 & 39.2 & 26.9 & 10.9 & 18.6 \\
\hline 2004 & 37.4 & 42.6 & 27.4 & 14.6 & 21.1 \\
\hline 2005 & 35.5 & 41.0 & 26.9 & 11.9 & 17.8 \\
\hline 2006 & 31.9 & 37.6 & 24.1 & 10.6 & 15.6 \\
\hline 2007 & 25.8 & 30.3 & 21.6 & 9.2 & 13.6 \\
\hline 2008 & 27.4 & 29.7 & 25.5 & 10.8 & 15.3 \\
\hline 2009 & 26.3 & 29.2 & 24.0 & 9.8 & 13.8 \\
\hline 2010 & 21.4 & 24.4 & 19.2 & 6.9 & 10.0 \\
\hline 2011 & 20.6 & 22.2 & 19.6 & 6.0 & 9.4 \\
\hline 2012 & 24.0 & 25.5 & 23.1 & 7.9 & 11.5 \\
\hline 2013 & 24.7 & 26.4 & 24.2 & 7.8 & 11.3 \\
\hline 2014 & 26.7 & 29.5 & 26.0 & 9.1 & 11.5 \\
\hline 2015 & 28.9 & 29.4 & 25.5 & 7.8 & 12.6 \\
\hline 2016 & 25.6 & 26.2 & 24.4 & 10.8 \\
\hline 2017 & 24.7 & 3.0 & & 11.8 \\
\hline
\end{tabular}

Note: The state-holding enterprises include state-owned and state-controlled enterprises.

Source: CEIC China Database. 


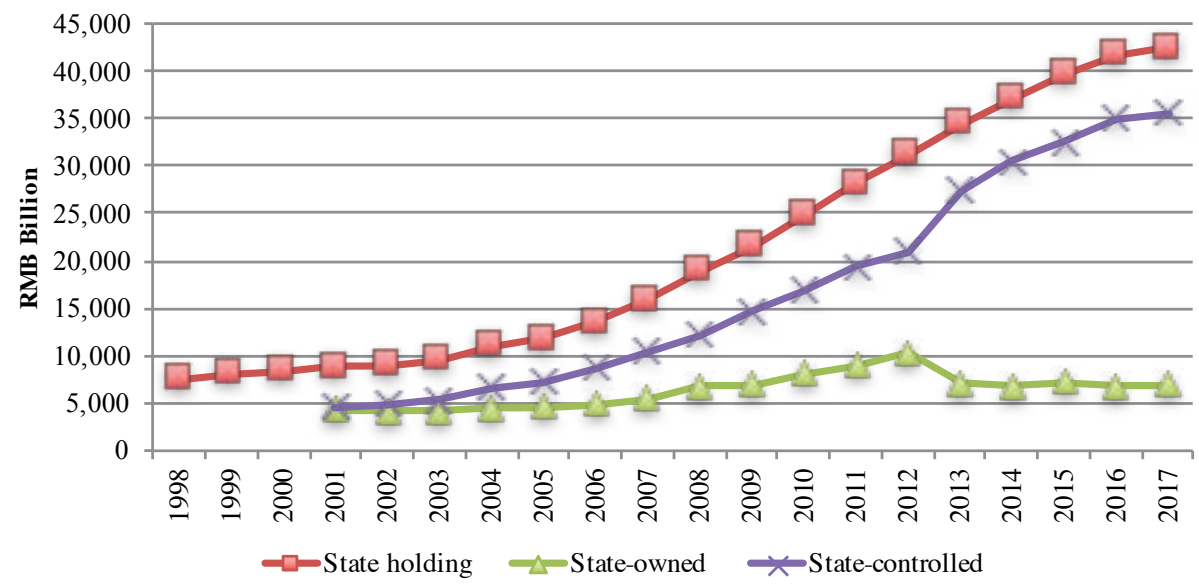

Figure A19.1 Total assets of state-owned and state-controlled enterprises, 1998-2017 (RMB billion, current price)

Note: The state-holding enterprises include state-owned and state-controlled enterprises.

Source: CEIC China Database.

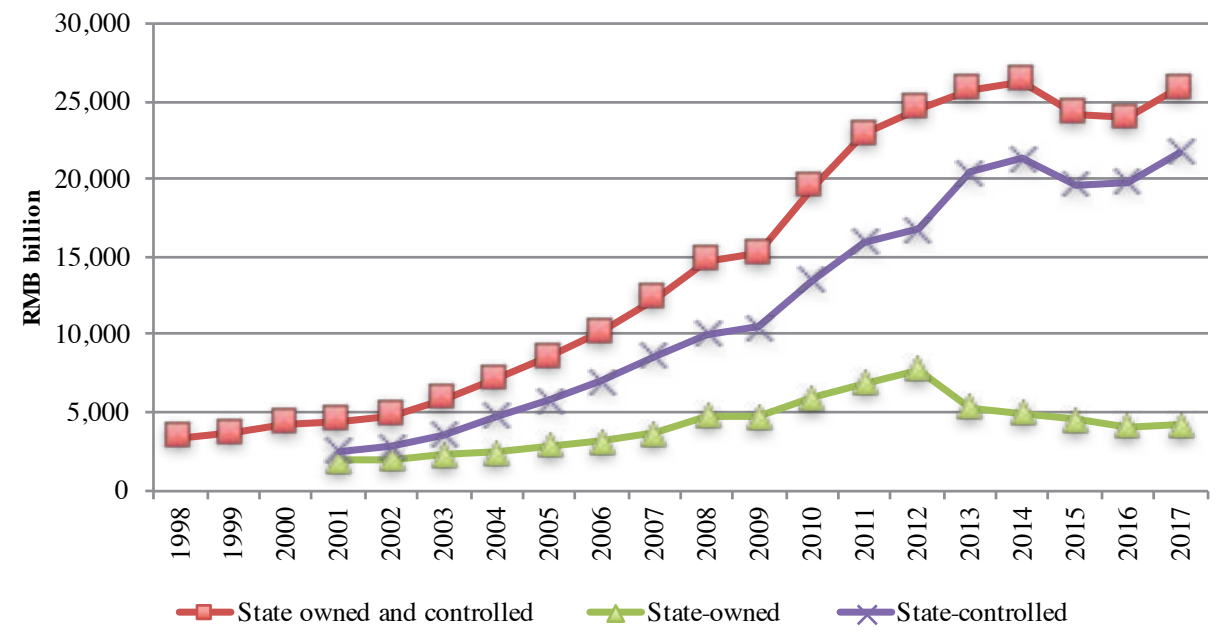

Figure A19.2 Output value of state-holding enterprises, 1998-2017 (RMB billion, current price)

Note: The state-holding enterprises include state-owned and state-controlled enterprises.

Source: CEIC China Database. 


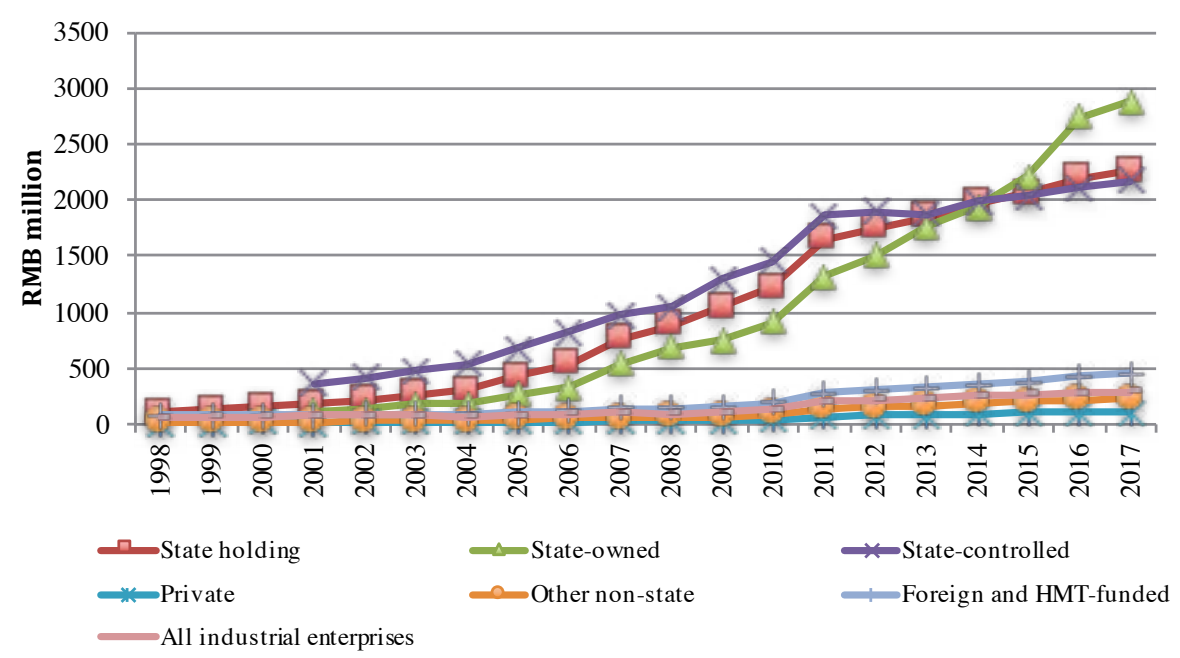

Figure A19.3 Average size of industrial enterprises by ownership type, 1998-2017 (total assets, RMB billion, current price)

Note: The state-holding enterprises include state-owned and state-controlled enterprises.

Source: CEIC China Database.

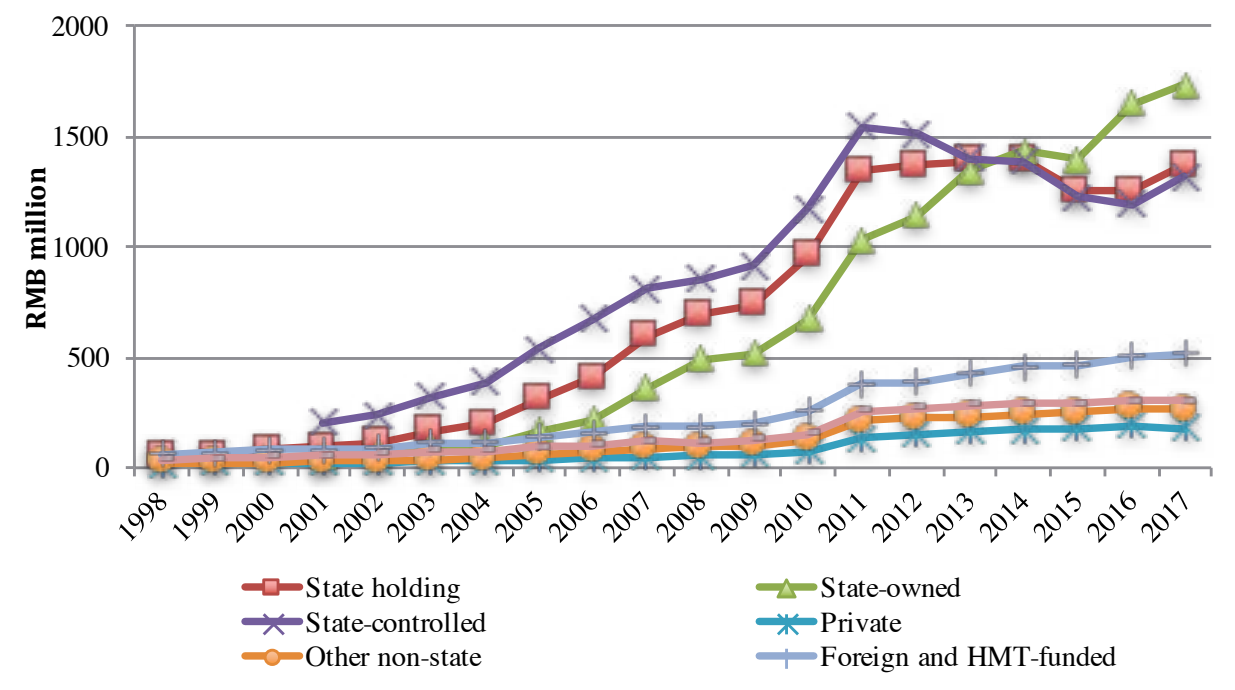

Figure A19.4 Average size of industrial enterprises by ownership type, 1998-2017 (sales output, RMB billion, current price)

Note: The state-holding enterprises include state-owned and state-controlled enterprises.

Source: CEIC China Database. 
This text is taken from China's 40 Years of Reform and Development: 1978-2018, edited by Ross Garnaut, Ligang Song and Cai Fang, published 2018 by ANU Press, The Australian National University, Canberra, Australia.

doi.org/10.22459/CYRD.07.2018.19 